\title{
PENDEKATAN FAITH LEARNING DALAM PEMBELAJARAN MATEMATIKA
}

\author{
Kartini Hutagaol \\ Fakultas Keguruan dan Ilmu Pendidikan \\ Universitas Advent Indonesia \\ kartinih_smant@yahoo.com
}

\begin{abstract}
Abstrak: Para guru perlu menyadari bahwa tidak ada cara tunggal untuk belajar yang paling benar, tidak ada cara untuk mengajar yang terbaik atau unggul, karena orang-orang berbeda dalam kemampuan, sikap, dan kepribadian intelektual. Tidak ada cara 'ujian yang benar' untuk belajar atau cara 'terbaik' untuk mengajar. Guru bebas memilih cara dan gaya mereka sendiri dalam proses belajar mengajar untuk mencapai tujuan yang telah ditentukan dengan mempertimbangkan kondisi masing-masing siswa. Namun ada sedikit pesan dalam materi pelajaran khusus pengajaran matematika di kelas yang menciptakan kesan setiap siswa ketika mereka meninggalkan kelas siswa diharapkan untuk mendiskusikan hal-hal menyenangkan yang telah terjadi, di samping matematika, ke kursus matematika baru diikuti, dan diharapkan bahwa mereka akan terus semangat membara sampai hari berikutnya. Untuk itu para guru membutuhkan upaya dan kesabaran seperti itu dalam memberikan motivasi yang benar. Motivasi yang kuat dalam mengajar matematika bukan hanya kata-kata, tetapi stimulasi melalui teknik mengajar sebagai cara yang tepat untuk membuat siswa senang dan lebih tertarik pada matematika. Cara-cara itu diharapkan dapat menghilangkan masalah seperti ketakutan atau kecemasan matematika, yang merupakan masalah umum selama bertahun-tahun. Pembelajaran berbasis iman menghubungkan pembelajaran materi pelajaran tertentu dalam matematika dengan Firman Tuhan, siswa diarahkan selalu bersedia menerima kebijaksanaan dan pengetahuan tentang Tuhan. Mengajar yang mengarah pada metode pengajaran surgawi untuk mengasihi Tuhan. Mengajar sesuai dengan kriteria yang tertulis dalam kitab Galatia 5: 22-23, yang mana; cinta, sukacita, kedamaian, kesabaran, kebaikan, kebaikan, kesetiaan, kelembutan, dan pengendalian diri. Harapan dengan mengintegrasikan iman dalam pengajaran matematika adalah membentuk siswa karakter keilahian untuk kehidupan sekarang dan kekal yang akan datang.
\end{abstract}

Kata Kunci: Mengintegrasikan Iman dalam Pembelajaran, Pengajaran Matematika.

Abstract: Teachers needs to be aware that there is no single way to learn the most correct, there is no way to teach the best or superior, because peoples are differ in intellectual abilities, attitudes, and personality. There can be no 'right test' way to study nor 'best' way to teach. Teachers are free to choose their own way and style in teaching and learning to achieve the goals that have been determined by considering the conditions of each student. But there is a little message in the particular subject matter of mathematics teaching in the classroom that create an impression of each student when they leave the classroom students are expected to discuss pleasant things which has happened, beside mathematics, to the new math course followed, and it is expected that they will continue to smolder spirit until the next day. Therefor teachers need such effort and patience in providing the right motivation. Strong motivation in mathematics teaching is not just words, but stimulation through teaching techniques as the proper way to make students happy and more interested towards mathematics. The ways that expected to eliminate problems such as fear or mathematics anxiety, which is a common problem for many years. Faith based learning correlates learning particular subject matter in mathematics with the Word of God, students are directed always willing accept wisdom and knowledge of God. Teaching that leads to the heavenly teaching method to love God. Teaching in accordance with the criteria written in the book of Galatians 5:22-23, which are; love, joy, peace, patience, kindness, goodness, faithfulness, gentleness, and selfs control. The 
expecttation by integrating faith in the teaching of mathematics is to form student Godly character for present and eternal life to come.

Keywords: Integrating Faith in Learning, Mathematics teaching.

\section{PENDAHULUAN}

Guru yang baik mestinya memikirkan bagaimana ide-ide matematika diajarkan di kelas dan bagaimana seharusnya anak-anak didiknya belajar di kelas, serta menentukan suatu tujuan atau sasaran yang akan dicapai. Untuk mencapai tujuan tersebut guru harus melakukan perencanaan dengan matang mulai dalam memilih strategi, pendekatan ataupun metode yang tepat sehingga diperoleh hasil yang oftimal, berhasil guna dan tepat guna (Soedjadi, 1999). Guru memilih, menyusun cara-cara yang ditempuh dalam pelaksanaan pembelajaran agar ideide matematika yang disajikan dapat beradaptasi dengan siswa, sehingga siswa ikut terlibat aktif di kelas dan sebaiknya pembelajaran diupayakan terpusat pada anak didik.

Guru sebagai pengajar perlu menyadari bahwa tidak ada cara belajar yang tunggal yang paling benar, tidak ada cara mengajar yang paling baik atau yang lebih unggul, sebab orang berbeda dalam kemampuan intelektual, sikap, dan kepribadian. Seperti yang diungkapkan oleh Nisbet (Suherman dkk, 2001) “There can be no 'right' way to study or 'best' way to teach...". Hal ini berarti masing-masing guru bebas memilih cara dan gayanya sendiri dalam belajar dan mengajar untuk mencapai sasaran yang sudah ditentukan.

Untuk mencapai sasaran yang sudah ditentukan seorang guru dapat menerapkan salah satu strategi, pendekatan, metode yang cocok dengan mempertimbangkan kondisi siswa. Tetapi ada sedikit pesan dalam mengajarkan materi pelajaran di kelas, yaitu memunculkan kesan dari setiap siswa yang akan meninggalkan ruangan kelas, diharapkan mereka akan memperbincangkan sesuatu yang menyenangkan yang telah terjadi pada pelajaran matematika yang baru saja diikuti, dan diharapkan semangat mereka akan terus membara sampai hari-hari berikutnya, dan mereka ingin sekali kembali mendapat pelajaran matematika untuk mendapatkan materi pelajaran yang lebih banyak lagi. Untuk itu guru perlu usaha memberikan motivasi yang benar, motivasi yang kuat dalam pengajaran matematika bukan hanya dengan kata-kata, tetapi dengan memberi rangsangan melalui kiat (strategi), trik, tehnik dan cara pengajaran yang tepat agar siswa senang, atau tertarik terhadap matematika. Diharapkan dengan cara yang demikian kita dapat memunculkan ketertarikan siswa terhadap matematika dan dapat menghilangkan masalah-masalah seperti kegelisahan terhadap matematika, yang merupakan masalah umum selama bertahun-tahun.

Anak-anak didik akan belajar matematika dengan baik, bila mereka benar-benar tertarik terhadap pelajaran matematika. Akan tetapi sulit bagi kebanyakan guru untuk menemukan 
persediaan gagasan tentang menyampaikan topik matematika secara menarik. Banyak guru terlibat dalam rutinitas menyampaikan materi pelajaran jarang meluangkan waktu, memikirkan atau mencari hal-hal yang dapat memotivasi siswa untuk tertarik dengan pelajaran matematika. Semestinya guru perlu waktu untuk merancang suatu pembelajaran dalam menanamkan konsep-konsep matematika yang menjadi sesuatu yang menarik dan menyenangkan dan diharapkan anak-anak didik maupun guru menunggu pelajaran matematika dan menjadi harapan akan merasa menyesal bila jam pelajaran matematika berakhir.

Sebagai guru/dosen perlu tanggap akan situasi dan kondisi yang memerlukan kesadaran dalam memahami kelabunya moral generasi penerus. Kita semua perlu keluar dengan sadar dari kubangan moral yang telah membelenggu, tanpa mencari siapa yang salah, tetapi perlu melakukan introspeksi dengan jujur dan bertekad serta bertindak melakukan perbaikan demi masa depan generasi pengganti, bukan generasi penerus keterbelengguan, tetapi generasi pengganti untuk masa depan. Dengan demikian pembelajaran dengan pendekatan; strategi; metode; ataupun model yang berlandaskan faith learning menjadi pusat perhatian. Pembelajaran yang menghidupkan hubungan yang akrab dengan Allah dan memahami akan Firman-Nya, anak-anak didik diarahkan selalu sedia menerima hikmat dan pengetahuan dari Allah, dan menghubungkan pelajaran

\section{Pembelajaran Berlandaskan Integrating Faith and Learning}

Dalam pembelajaran berlandaskan faith learning, ditekankan bahwa guru/dosen harus mampu membentuk karakter (tabiat) siswa dengan landasan kasih. Dengan kata lain, guru memiliki peran penting dalam perkembangan tabiat anak didiknya. "Pembangunan tabiat (karakter) adalah pekerjaan yang sangat penting yang pernah dipercayakan kepada manusia; dan tidak pernah sebelumnya begitu penting dipelajari seperti sekarang ini” (Education, hal.225). Pembelajaran berlandaskan faith learning adalah cara menciptakan suasana belajar yang menyenangkan, dengan memberi rangsangan melalui kiat (strategi), trik, tehnik pembelajaran, dan senantiasa menghubungkan topik pelajaran dengan firman Allah, dengan alam ciptaan Allah. Dalam menciptakan suasana belajar yang menyenangkan diperlukan ketenangan, sukacita, dan pemberian motivasi yang kuat dan benar dalam pengajaran matematika, bukan hanya dengan kata-kata, tetapi dengan memberi rangsangan melalui kiat (strategi), trik, tehnik dan cara pengajaran yang tepat agar siswa senang, atau tertarik terhadap matematika.

Pembelajaran berlandaskan faith learning mengarahkan pembelajaran terpusat pada siswa, dan menekankan pada belajar berpengertian. Memberikan tanggung jawab kepada siswa untuk mengkontruksi pengetahuannya sendiri serta kesempatan bertanya yang seluas-luasnya 
tentang ruang lingkup materi ajar. Menghidupkan hubungan yang akrab dengan Allah dan memahami akan Firman-Nya, dan siswa diarahkan selalu sedia menerima hikmat dan pengetahuan dari Allah. Dengan demikian pembelajaran dengan faith learning, diharapkan mampu membentuk karakter siswa dengan landasan kasih sesuai dengan iman, dan akan membawa siswa pada motivasi belajar yang tinggi terhadap matematika serta hasil belajar yang memuaskan, serta mampu menjadi diri sendiri.

Dengan membentuk karakter sebagai generasi pengganti, menjadi pelaku kebenaran yang mampu mengendalikan diri, suatu hari kelak mereka menjadi para pemimpin, para pemikir, para pembangun yang memiliki kebaikan, kesopanan, kelemah-lembutan, dan kejujuran. Didiklah seorang muda pada jalannya, maka pada masa tuanya dia tidak akan meninggalkannya, (Amsal 26: 6). Keadaan alamiah mempunyai tiga sisi, dan pelatihan yang diikuti oleh raja Solaiman mencakup pengembangan yang benar dari kekuatan-kekuatan fisik, mental dan moral. Untuk melakukan pekerjaan ini dengan tepat, para orang tua dan para guru haruslah terlebih dahulu mengerti "jalan kemana seorang anak akan pergi." Selanjutnya bahwa tidak ada pekerjaan yang setiap kali dikerjakan oleh manusia, menuntut kepedulian dan ketrampilan yang lebih besar daripada melatih dan mendidik orang-orang muda dan anak-anak dengan tepat (White, 1882). Dengan demikian mereka putra putri bangsa sebagai generasi pengganti akan menjujung tinggi moral, mereka akan bertekad serta bertindak melakukan perbaikan di bumi yang kita cintai ini.

Sejauh memungkinkan, setiap anak haruslah dilatih untuk mandiri. Dengan menyuruhnya mengadakan latihan di dalam banyak macam pelajaran, dia akan belajar mengenali kekuatan dan kelemahannya sendiri. Seorang guru yang bijak akan memberikan perhatian khusus untuk mengembangkan bagian mana yang paling lemah, agar anak tersebut dapat membentuk tabiat yang seimbang dan harmonis. Tenaga pengajar yang melatih muridmuridnya untuk merasakan kekuatan yang ada didalam dirinya untuk menjadi orang terhormat dan bemberikan manfaat oleh orang-orang yang ceroboh, dan pekerjaannya sering tidak dinilai berguna, akan menjadi pelatih yang paling sukses. Pekerjaan mereka mungkin dinilai tidak seperti pelatih yang hebat, tetapi ingatlah masa depan anak-anak itu akan menampakkan hasil dari rencana pendidikan yang lebih baik. Dalam setiap bidang pengajaran, para guru harus berusaha menanamkan terang dari firman Allah, dan menunjukkan pentingnya penurutan kepada Firman Allah. Karena setiap putra putri (anak didik) harus layak disebut sebagai anakanak Allah, dengan demikian pendidikan mestinya mengarah pada kasih Allah atau pengajaran surgawi. Tidak ada pekerjaan yang setiap kali dikerjakan oleh manusia, menuntut kepedulian 
dan ketrampilan yang lebih besar daripada melatih dan mendidik orang-orang muda dan anakanak dengan tepat.

Mendidik murid adalah suatu pekerjaan yang sangat penting. Guru/dosen harus merasa panggilan Allah yang kudus, dan menyerahkan dirinya kedalam pekerjaan itu dengan semangat dan penuh pengabdian. Sehingga akan diperoleh pendidikan yang sejati yaitu perkembangan yang harmoni dan seimbang di antara fisik, mental dan spiritual. Menjadikan siswa yang siap sedia menjadi orang yang selalu gembira, siap melayani di masa yang akan datang. Sanggup membawa hikmat dan pengetahuan yang suci ke dalam pekerjaannya yang berguna untuk hidupnya dan untuk masa yang akan datang, yakni hidup yang kekal. (Counsels to parents, teachers, students, hal. 229.). Untuk itu para guru perlu persipan diri sebelum melakukan tugastugas yang mulia ini dengan memperhatikan hal-hal berikut: 1) Merasakan pekerjaan itu penting. 2) Membuat persiapan yang baik. 3) Bersemangat dalam melakukannya. 4) Mengabdikan hidupnya kepada pekerjaaan itu.

Apabila guru/dosen memberikan perhatian terhadap anak-anak didik, dan menunjukkan kasih di hadapan mereka, bahkan mungkin menjadi contoh dan panutan dihadapan mereka, maka guru/dosen akan dapat memenangkan kasih sayang dan mengangkat rasa percaya diri murid-murid tersebut. Dengan demikian pelajaran mengenai rasa hormat dan penurutan akan lebih siap untuk diajarkan, karena kasih adalah guru yang paling baik. Para guru dan dosen yang melatih murid-muridnya untuk merasakan kekuatan yang ada di dalam dirinya untuk menjadi orang terhormat dan berguna, merasa malu dengan ketidak jujuran, akan menjadi pelatih yang paling sukses. Pekerjaan mereka mungkin dinilai tidak memberikan manfaat dan pekerjaannya tidak dinilai setinggi seperti pelatih yang dapat menguasai murid-muridnya dengan sepenuhnya, tetapi masa depan murid-murid itu akan menampakkan hasil dari rencana pendidikan yang lebih baik.

Pembelajaran faith learning menghubungkan pelajaran dengan firman Allah, dan alam ciptaan tangan-Nya. Integrating Faith and Learning (IFL) memiliki kriteria-kriteria pembelajaran yang berdasarkan firman Allah seperti tertulis dalam buku Galatia 5:22-23; yaitu: kasih, sukacita, damai sejahtera, kesabaran, kemurahan, kebaikan, kesetiaan, kelemah lembutan, dan penguasaan diri.

\section{Kasih}

Kalau saja guru-guru atau dosen menunjukkan kasih pada kegiatan anak-anak didiknya, bahkan mungkin ikut terlibat dalam kegiatan mereka, maka guru/dosen dapat memenangkan kasih sayang dan mengangkat rasa percaya diri anak-anak didik tersebut. Selanjutnya pelajaran mengenai rasa hormat dan penurutan akan lebih siap untuk diajarkan, karena kasih adalah guru 
yang paling baik. Janganlah pernah dilupakan bahwa guru haruslah menjadi seperti yang diinginkannya bagi murid-muridnya, namun prinsip-prinsip dan perilakunya haruslah dapat dinilai lebih tinggi kepentingannya daripada kemampuannya yang didapat dari buku-buku. Para guru dan dosen haruslah menjadi orang yang takut akan Allah, dan merasakan tanggungjawab di dalam pekerjaannya.

Untuk memenangkan kasih sayang dari para anak-anak didik, guru/dosen harus dapat menunjukkan bahwa hatinya sendiri dipenuhi dengan kasih sayang di hadapan mereka, melalui pandangan matanya dan perkataannya dan tindakannya, kebiasaan-kebiasaan yang baik, dan mengembangkan perilaku yang terhormat. Kebiasaan ini merupakan pelatihan fisik yang seharusnya menempati tempat yang utama di dalam setiap hati para pendidik. Sehingga apabila guru/dosen dalam menyampaikan materi pelajaran yang dipenuhi belas kasih, akan mampu membangun minat dan motivasi anak didik terhadap matematika. Dan merupakan poin penting juga bahwa guru dalam menyampaikan materi ajar berusaha membelajarkan anak didik melalui belajar berpengertian, dengan memberikan trik-trik yang istimewa untuk mempermudah pemahaman siswa.

Selanjutnya karena merasa pekerjaan itu penting, guru melakukan persiapan yang baik atau perencanaan yang matang dan mengarahkan pemahaman siswa dengan pembelajaran bermakna, mengutamakan kepada pengertian, proses dan hasil akhir, khususnya dalam pembelajaran matematika, dan siswa digiring untuk mampu mengaitkan pengetahuan baru melalui pengetahuan lama. Sehingga memahami materi bukan sekedar tahu, tetapi mampu menjadi diri sendiri.

\section{Sukacita dan Rasa Syukur}

Guru dalam menyampaikan materi pelajaran memiliki rasa persahabatan yang menyenangkan, sehingga suasana kelas menjadi kondusif. Guru selalu berbesar hati dalam menyikapi latar belakang pengetahuan yang berbeda-beda dari setiap siswa. Latar belakang pengetahuan yang berbeda-beda dari setiap siswa bukan untuk dikeluhkan, tetapi disikapi sebagai tantangan dengan suka cita, sehingga guru menyajikan materi ajar yang memungkinkan siswa tertarik, termotivasi dan tertantang untuk terlibat dalam belajar. Guru menghilangkan segala perbedaan yang dimiliki siswa, berusaha memperlakukan siswa dengan adil, menghilangkan perasaan rendah diri. Karena setiap pendapat yang dimiliki siswa selalu dihargai walau terkecil sekalipun. Para siswa diarahkan untuk selalu bersyukur, karena dalam mempraktekkan rasa syukur kita akan cenderung lebih kreatif, bangkit kembali lebih cepat dari keterpurukan, memiliki sistem kekebalan tubuh yang lebih kuat, dan memiliki hubungan sosial yang lebih tinggi dibanding mereka yang tidak berlatih bersyukur. Salah satu cara yang jelas 
untuk merefleksikan bahwa kita ini hidup bersyukur adalah kita mempunyai wawasan hidup yang positif.

\section{Kesabaran, Kemurahan dan Kebaikan}

Dengan penuh kesabaran, guru berusaha menolong siswa dalam memunculkan keingintahuan atau kemauan untuk mau belajar dan terlibat aktip di dalam kelas, diharapkan mampu meredam kebosanan maupun kegusaran hati siswa. Dengan demikian diharapkan siswa duduk manis di kelas, tertarik dengan materi pelajaran yang diterima khususnya pelajaran matematika. Dengan persiapan yang baik, guru mengarahkan siswa untuk dapat mengkontruksi pemahaman matematikanya, mampu menemukan ide-ide atau konsep-konsep matematikanya, selanjutnya setelah konsep atau ide-ide matematika tersebut sudah dipahami oleh siswa, guru akan berulang-ulang mengingatkannya kepada siswa, guru akan selalu mengaitkan materi yang sudah dipelajari dengan materi berikutnya. Ajarlah anakmu berulangulang siang dan malam (Ulangan 6:7). Dengan demikian siswa mampu memahami materi bukan sekedar tahu, tetapi mereka diharapkan betul-betul paham dan mampu mengkontruksi sendiri pemahaman matematikanya, tidak bergantung pada orang lain, mampu menjadi diri sendiri tidak tergoda dengan ketidak jujuran.

Guru selalu siap sedia memberi pertolongan bila diperlukan (scaffolding) untuk mengantisipasi kemacetan dalam proses pembelajaran khususnya matematika. Mendorong dan mengajak untuk terjadinya suatu interaksi di dalam kelas, mengarahkan terjadinya saring ide di antara siswa. Dengan persiapan yang baik, guru dengan murah hati membagi ilmu pengetahuan (tidak pelit ilmu) terhadap siswa. Dengan penuh kesabaran menolong siswa yang lemah atau yang kurang mampu, dan selalu mengingatkan kepada siswa yang pandai untuk memiliki kerendahan hati dengan mengaitkan materi pelajaran dengan Firman Allah.

\section{Kesetiaan}

Guru sebagai pendidik harus menyadari bahwa kemajuan pendidikan lebih tergantung kepada dedikasi serta kreativitas guru. Guru sadar bahwa siswa hidup dalam kurun waktu yang penuh dengan persaingan yang akan mengalami banyak perubahan-perubahan yang akan terjadi dalam berbagai tempat, sehingga guru mesti memegang satu janji untuk selalu memperbaharui pelajaran dan pembelajarannya. Guru harus setia mau meningkatkan diri dalam bidang keilmuannya, baik melalui pendidikan formal maupun informal. Setia atau mempunyai kehendak yang kuat untuk merencanakan dan melaksanakan pembelajaran matematika dengan baik, dalam arti bahwa peserta didiknya benar-benar memahami matematika dengan baik sesuai dengan jenjang sekolahnya. Selanjutnya guru harus setia pada profesinya, dan menghargai setiap pekerjaan yang ia lakukan sebagai panggilan dari Allah. 


\section{Kelemah-lembutan}

Dengan kelemah lembutan menanamkan nilai didik yang membantu membentuk karakter siswa, berusaha mengarahkan pembelajaran terpusat pada siswa, dengan memberikan kesempatan kepada siswa untuk ikut aktif belajar. Dengan kelemah lembutan mengarahkan siswa untuk mampu menjadi diri sendiri, belajar dengan mengkontruksi pengetahuan, mampu melakukan proses menuju hasil. Dengan kelemah lembutan mengarahkan siswa dalam membangun kemampuan penalaran, kemampuan pemecahan masalah, kemampuan komunikasi, kemampuan koneksi dan kemampuan representasi matematis siswa khususnya yang akan membantu siswa apabila kelak menghadapi berbagai masalah dan kehidupan sehariharinya. Perlu disadari bahwa untuk dapat mengetahui apakah nilai didik pembentuk karakter siswa telah tercapai tidaklah mudah, lebih-lebih dalam kurun waktu yang singkat, untuk itu diperlukan upaya dengan penuh kesabaran dan terencana, kontinu dan pengatan yang cukup lama.

\section{Penguasaan Diri}

Adalah baik dalam pertumbuhan karakter siswa, bila mereka senantiasa berhadapan dengan para guru atau pendidik yang selalu mengusahakan kasih sayang, simpati dan kelembutan, diharapkan menghindari kekasaran atau kekerasan di dalam kelas. Dengan kebaikan kesopanan, kelemah-lembutan, dan kejujuran adalah memiliki kemampuan yang sangat berharga untuk ditiru, atau diteladani siswa. Para guru/dosen harus bertanggung jawab untuk mengendalikan diri, guru harus menguasai diri dalam segala hal di hadapan siswa, sebab guru/dosen yang mereka percayai harus benar menjadi suri teladan di hadapan mereka. Jangan melukai hati mereka, mari kita bekerja dengan sopan santun, hormat, penuh kesabaran dan kebaikan.

Kita bekerja mengarahkan pengetahuan mereka menjadi manusia yang berkarakter, mengarahkan mereka menjadi pemikir, tetapi kita harus mampu mengendalikan diri kita lebih dahulu, sehingga mereka akan menjadi pelaku kebenaran yang mampu mengendalikan diri, suatu hari kelak mereka menjadi para pemikir, para pemimpin, para pembangun yang memiliki kebaikan kesopanan, kelemah-lembutan, dan kejujuran. Mereka akan berdiri kelak di atas kebenaran, mereka akan bekerja dengan penuh perhatian berlaku adil dan baik, tabiatnya akan bertumbuh mirip dengan tabiat Ilahi. Suatu hari kelak mereka akan mampu bertanggung jawab, mampu memberi pembetulan teguran yang penuh hikmat kepada yang bersalah, dengan penuh kasih dan kelemah-lembutan, saling mengingatkan untuk sama-sama bertumbuh dalam kasih, sama-sama bertumbuh dalam kebenaran. Mereka akan menjujung tinggi moral bangsa kita, mereka akan bertekad serta bertindak melakukan perbaikan di bumi pertiwi yang kita cintai ini. 


\section{Ing Ngarsa Sung Tulada, Ing Madya Mangun Karsa, Tut Wuri Handayani}

Konsep pembelajaran faith learning sejalan dengan gagasan tokoh pendidikan Ki Hajar Dewantara "Ing Ngarsa Sung Tulada, Ing Madya Mangun Karsa, Tut Wuri Handayani”. Memberi makna apabila berada di depan memberi contoh di tengah membangun kehendak yang baik, dan bila di belakang memberi dukungan atau dorongan untuk mencapai tujuan yang baik.

Seorang pendidik (guru/dosen) di manapun ditempatkan harus melakukan tugas-tugas mulia. Seorang guru adalah seorang pemimpin. Sebagai seorang pemimpin, guru mestinya dapat memberi contoh baik kepada yang dipimpin. Memberi contoh yang baik untuk ditiru dan diteladani, berusaha menunjukkan dan menanamkan terang dari firman Allah, dan menunjukkan penurutan kepada firman Allah. Di tengah sebagai seorang fasilitator mampu membangun kehendak yang baik menunjukkan kasih, dan dengan penuh kesabaran dalam mencapai tujuan, dan sebagai dinamisator membangkitkan semangat, mudah menyesuaikan diri dengan keadaan, mampu memberi dorongan dengan penuh semangat kepada kelompok untuk mencapai tujuan bersama.

Bila seorang guru menyampaikan suatu informasi ataupun suatu konsep melalui metode ceramah, maka dapat dikatakan ia dikatakan sedang berfungsi "Ing Ngarsa Sung Tulada". Ia mestinya benar-benar siap dan tahu benar bahwa contoh konsep yang diberikan adalah baik dan benar dan selalu berusaha mengaitkan dengan firman Allah.

Bila seorang guru sedang melaksanakan model pembelajaran dengan kelompok kecil, atau diskusi siswa, dan melihat arah diskusi tidak cocok dengan tujuan pembelajaran, dan dengan kesabaran dan kelemah lembutan guru mengajukan pertanyaan untuk meluruskannya. Maka guru/dosen dikatakan berfungsi sebagai "Ing Madya Mangun Karsa". Tetapi bila saat diskusi berjalan dengan baik dan yang berbicara adalah siswa tertentu saja, maka guru dapat memberi dorongan agar siswa yang lain juga ikut mengajukan pendapat, dengan penuh kasih berusaha membangkitkan semangat siswa yang lain untuk ikut serta berpartisipasi. Guru/dosen mengarahkan, mendorong dan membentuk tabiat siswa dengan landasan kasih, maka guru berfungsi sebagai Tut Wuri Handayani.

Kasih memancar dari dalam hati, sebab itu peliharalah kasih di dalam hati. Bukalah lebarlebar pintu hatiku terhadap kasihmu ya Allah. Biarlah kasih setiaMu menguasai hidupku, sebab itu yang akan membuat hatiku lemah-lembut. Mazmur (123:23). Selidikilah aku, ya Allah, dan kenallah hatiku. Ujilah aku dan kenallah pikiran-pikiranku.

\section{Contoh Pembelajaran Berlandaskan Faith Learning}


Dalam suatu kegiatan belajar mengajar, inisiatif dimulai dari guru. Dengan mengajukan pertanyaan-pertanyaan melalui pemberian ilustrasi, siswa diarahkan untuk menggali informasi, mengaktifkan pengetahuan lama, supaya siswa terlibat aktif. Dengan penuh kelemah-lembutan guru/dosen selalu menghargai jawaban, pertanyaan, keluhan, atau tindakan siswa, walaupun jelek mutunya. Dalam suasana gembira, pemahaman siswa diarahkan menerima hal-hal yang baru dengan berpengertian, bermakna, bukan hanya sekedar tahu, tetapi benar-benar memahami dan diharapkan mampu mengaplikasikannya dalam kehidupan kesehariannya. Anak didik mampu menemukan ide-ide atau konsep, teorema, rumus, pola atau aturan, dan sejenisnya. Guru/dosen memberi kebebasan terhadap siswa untuk dapat menduga, menerka, mencoba-coba, memperkirakan, dan usaha lainnya dengan menggunakan pengetahuan siapnya melalui cara induksi, deduksi, observasi, dan sejenisnya. Dengan meminta hikmat dan pengetahuan dari Allah, guru memikirkan suatu aplikasi nyata, dari materi yang dipelajari, atau memberi motivasi, paling tidak menggiring pemahaman metematikanya. Menemukan aplikasi dari matematika yang sesuai merupakan tugas yang tidak sederhana, dan kadang aplikasi dari suatu topik kadang sulit ditemukan dari pada topik yang lain, untuk itu perlu ketekunan, dan hikmat dari Allah.

\section{Pembelajaran Faith Learning pada Perkalian dalam Bentuk Aljabar}

Untuk mempelajari perkalian dua digit atau lebih, dapat menunjukkan beberapa format yang berbeda untuk proses yang sama. Menemukan pola, aturan atau rumus $(a+b)^{2}=a^{2}+2 a b+b^{2}$, dan dapat memahami aplikasinya dalam kehidupan sehari-hari. Guru menyajikan bentuk perkalian dalam beberapa format yang berbeda dengan proses menuju hasil: Langkah demi langkah disajikan sebagai berikut:

1. Dengan penuh kasih dan kesabaran memperkenalkan cara-cara perkalian.

1.1 Memperkenalkan Perkalian antar 78 dengan 63 dengan cara perkalian panjang sebagai berikut:

$$
\begin{gathered}
78 \\
63 \times \\
234 \\
468+ \\
\hline 4914
\end{gathered}
$$

Maka diperoleh hasilnya 4914

1.2 Kemudian memperkenalkan perkalian antar 78 dan 63 dengan cara menggunakan tabel atau dengan menggunakan konsep luas sebagai berikut: 


\begin{tabular}{l|l|l|}
\multicolumn{1}{c}{} & \multicolumn{1}{l|}{60} & \multicolumn{1}{l}{3} \\
\cline { 2 - 3 } 70 & 4200 & 210 \\
\cline { 2 - 3 } & & \\
\cline { 2 - 3 } 8 & 480 & 24 \\
\cline { 2 - 3 } & &
\end{tabular}

$$
\begin{aligned}
\text { Maka } 78 \times \mathbf{6 3} & =(70 \times 60)+(70 \times 3)+(8 \times 60)+(8 \times 3) \\
& =4200+210+480+24 \\
& =4914
\end{aligned}
$$

2. Dengan penuh sukacita guru/dosen selalu berbesar hati dalam menyikapi latar belakang pengetahuan yang berbeda-beda dari setiap anak didik, mengulang langkah demi langkah. (Ulangan 6:7 Mengingatkan, mengajarkannya berulang-ulang).

2.1 Mengulangi langkah 1 dengan contoh yang berbeda. Memperkenalkan perkalikan antar 72 dengan 79 dengan cara perkalian panjang sebagai berikut:

$$
\begin{gathered}
72 \\
\frac{79 \times}{648} \\
504+ \\
\hline 5688
\end{gathered}
$$

Maka diperoleh hasilnya 5688

2.2 Kemudian memperkenalkan perkalian antar 72 dan 79 dengan cara menggunakan tabel atau dengan menggunakan konsep luas sebagai berikut:

\begin{tabular}{l|l|l|}
\multicolumn{1}{c|}{70} & \multicolumn{1}{l}{9} \\
\cline { 3 - 3 } 70 & 4900 & 630 \\
\cline { 2 - 3 } 2 & 140 & 18 \\
\cline { 2 - 3 } & & \\
\cline { 2 - 3 } & &
\end{tabular}

Maka hasil kali antara 72 dan $79=(70 \times 70)(70 \times 9)(2 \times 70)(2 \times 9)$

$$
\begin{aligned}
& =4900+630+140+18 \\
& =5688
\end{aligned}
$$

3. Dengan penuh kesetiaan guru/dosen menggiring kemampuan-kemampuan matematis anak didik untuk dapat menemukan konsep matematika.

3.1 Anak didik diarahkan mengikuti langkah 1 dan langkah 2, siswa menghitung luas daerah I, II, III, IV, dan luas daerah keseluruhan dari model geometri berikut ini. 
Luas daerah I $\quad=$

Luas daerah II $=$

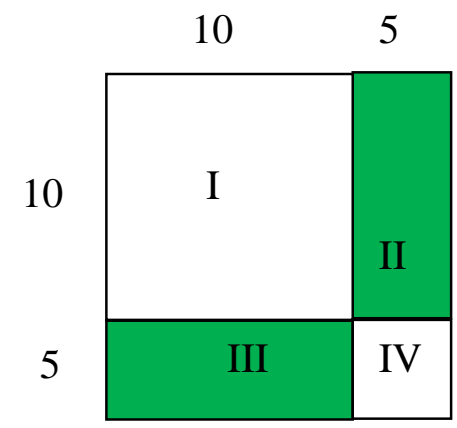

Luas daerah III =

Luas daerah IV =

Luas keseluruhan $=$

Siswa diarahkan untuk menemukan bahwa hasil kali: $15 \times 15$

$$
\begin{aligned}
=(\mathbf{1 0}+\mathbf{5}) \text { dan }(\mathbf{1 0}+\mathbf{5}) & =(10)^{2}+2(10 \times 5)+(5 \times 5) \\
& =100+(2 \times 50)+25 \\
& =225
\end{aligned}
$$

4. Dengan kelemah lembutan guru/dosen mengarahkan siswa dalam membangun kemampuan penalaran, kemampuan pemecahan masalah, kemampuan komunikasi, kemampuan koneksi dan kemampuan representasi matematis siswa khususnya yang akan membantu siswa apabila kelak menghadapi berbagai masalah dan kehidupan sehari-harinya. Anak didik diarahkan untuk mampu mengaplikasikan masalah matematikanya dalam kehidupan sehari-hari.

4.1 Anak didik mampu melihat bahwa perkalian antar $15 \times 15$ adalah:

$$
100+50+50+25=225 \text {. }
$$

4.2 Dengan penuh kesabaran siswa diarahkan untuk memahami aplikasinya, mengembangkan untuk lebih luas, dan mampu menemukan konsep matematika, sebagai berikut: Anak didik mampu menemukan luas daerah I, II, III, IV, dan luas daerah keseluruhan dari model geometri berikut ini:

a $\quad b$

$$
\begin{aligned}
& \text { Luas daerah I } \quad=a^{2} \\
& \text { Luas daerah II } \quad=a b \\
& \text { Luas daerah III } \quad=a b \\
& \text { Luas daerah IV } \quad=b^{2}
\end{aligned}
$$

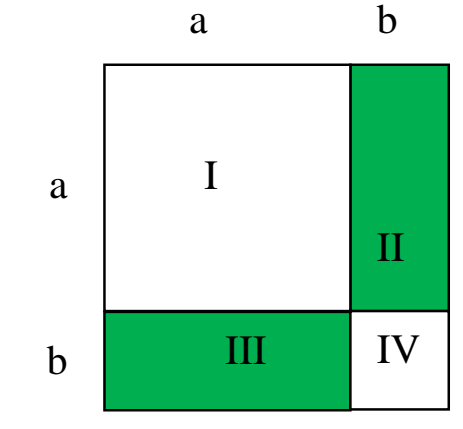

$$
\begin{aligned}
& \text { Luas keseluruhan }=(a+b)^{2}=a^{2}+a b+a b+b^{2} \\
& =a^{2}+2 a b+b^{2}
\end{aligned}
$$

4.3 Anak didik digiring melihat hubungan antara luas keseluruhan dan luas daerah I, II, III, IV. Kemudian anak didik berkemampuan menemukan rumus dan konsep perkalian dua digit. 


$$
(a+b)^{2}=(a+b)(a+b)=a^{2}+a b+a b+b^{2}=a^{2}+2 a b+b^{2}
$$

5. Dengan kelemah lembutan guru/dosen mengarahkan siswa dalam membangun dan mengembangkan kemampuan penalaran, kemampuan pemecahan masalah, kemampuan komunikasi, kemampuan koneksi dan kemampuan representasi matematis siswa dalam situasi yang lain.

5.1 Diharapkan anak didik mampu mengembangkan kemampuannya dalam situasi yang lain, misalnya $47 \times 89=40 \times 80+40 \times 9+80 \times 9+7 \times 9$

$$
\begin{aligned}
& =3200+360+560+63 \\
& =4183
\end{aligned}
$$

5.2 Anak didik diarahkan untuk menemukan konsep perkalian dua digit atau perkalian antar puluhan dengan puluhan sebagai berikut: hasil dari perkalian puluhan dikali puluhan dijumlahkan dengan hasil dari perkalian puluhan dikali satuan dijumlahkan dengan hasil dari perkalian satuan dikali puluhan dijumlahkan dengan satuan dikali satuan.

5.3 Anak didik digiring untuk mampu memahami konsep perkalian dua digit atau lebih dalam bentuk aljabar dalam kehidupan sehari-hari, mampu memahami koefisien pada perkalian dalam bentuk aljabar, dan diarahkan mampu memperluas kemampuankemampuan matematisnya memahami koefisien-koefisien dengan pola segitiga pascal.

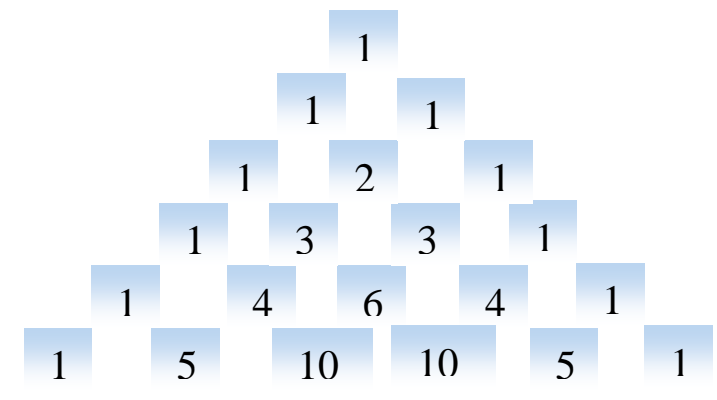

5.4 Guru/dosen melalui pemberian scaffolding menggiring anak didik, untuk dapat mengkontruksi pemahamannya, mengkoneksikan, memperluas pemahamannya terhadap pokok bahasan yang lain. Guru/dosen membiasakan pemahaman anak didik untuk tidak terpisah-pisah atau terkotak-kotak dengan topik-topik yang lain atau pokok-pokok bahasan yang lain. Misalnya sedini mungkin dengan membahas topik perkalian dalam bentuk aljabar diharapkan untuk memperkenalkan konsep pola segitiga pascal dengan topik himpunan bagian dan topik peluang.

Contoh menemukan pola, aturan atau rumus $(a+b)(a-b)=a^{2}-b^{2}$ 
1. Dengan penuh kasih dan kesabaran guru memperkenalkan cara-cara menemukan pola, aturan atau rumus $(a+b)(a-b)=a^{2}-b^{2}$, dan dapat memahami aplikasinya dalam kehidupan sehari-hari. Guru menyajikan bentuk perkalian dalam beberapa format yang berbeda dengan proses yang sama

1.1 Memperkenalkan perkalian $\operatorname{antar}(\mathbf{1 0}+\mathbf{5})$ dan $(\mathbf{1 0}-\mathbf{5})$ sebagai berikut:

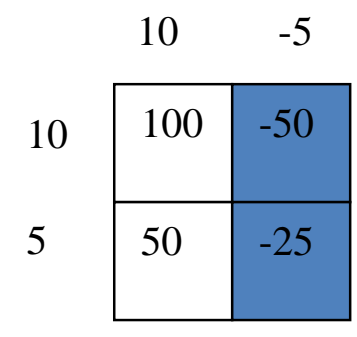

$$
\text { Sehingga } \begin{aligned}
(\mathbf{1 0}+\mathbf{5}) \times(\mathbf{1 0}-\mathbf{5}) & =(10 \times 10)-(10 \times 5)+(5 \times 10)-(5 \times 5) \\
& =100+50-50-25 \\
& =100-25 \text { atau } 10^{2}-5^{2} \\
& =100-25 \\
& =\mathbf{7 5}
\end{aligned}
$$

2. Dengan penuh kesabaran dan sukacita guru/dosen memperkenalkan perkalikan antar $11 \times 9$, dan menggiring pemahaman anak didik bahwa $11=10+1$; dan $9=10-1$

$$
\begin{aligned}
\text { Maka hasil kali } 11 \text { dan } 9 & =(10+1)(10-1) \\
& =100+10-10-1 \\
& =100-1 \\
& =99
\end{aligned}
$$

3. Dengan penuh kesetiaan guru/dosen menggiring kemampuan-kemampuan matematis anak didik untuk dapat menemukan konsep matematika.

3.1 Selanjutnya siswa digiring menebak hasil perkalian dari $\mathbf{2 1} \times \mathbf{1 9}$

$$
\begin{aligned}
& 21=20+1 \\
& 19=20-1 \\
& \text { Maka hasil kali antar } 21 \text { dan } 19=20^{2}-1^{2} \\
& =400-1 \\
& =399
\end{aligned}
$$

3.2 Untuk lebih mendalami kemampuan penalaran dan kemampuan koneksi matematis siswa diulangi lagi dalam menghitung perkalian antar $81 \times 79$

Siswa akan menemukan hasil perkalian antar 81 dan 79 adalah $6400-1=6399$ 
3.3 Anak didik digiring untuk mengembangkan kemampuannya dalam situasi yang lain, misalnya hasil perkalian antar 104 dan 96 adalah $10000-16=9984$

4. Dengan kesabaran dan ketekunan guru/dosen menggiring anak didik untuk menemukan rumus dan konsep matematik bahwa:

$$
\begin{aligned}
& (a+b)(a-b)=a^{2}-a b+a b-b^{2}=a^{2}-b^{2} \\
& (a+b)(a-b)=a^{2}-b^{2}
\end{aligned}
$$

Rekomendasi yang dapat disampaikan berdasarkan uraian di atas adalah sebagai berikut:

1. Pembelajaran berlandaskan Integrating Faith and Learning (IFL) adalah belajar dengan landasan kasih, menghidupkan hubungan yang akrab dengan Allah dan memahami akan Firman-Nya, siswa diarahkan selalu sedia menerima hikmat dan pengetahuan dari Allah. Dengan demikian pembelajaran dengan faith learning, diharapkan mampu membentuk karakter siswa dengan landasan kasih sesuai dengan iman, dan akan membawa anak didik pada motivasi belajar yang tinggi terhadap matematika serta hasil belajar yang memuaskan, yang akan mampu menjadi diri sendiri.

2. Dengan IFL akan membentuk karakter anak didik sedini mungkin, sebagai generasi pengganti sebagai pelaku kebenaran yang mampu mengendalikan diri, di suatu hari kelak mereka menjadi para pemimpin, para pemikir, para pembangun yang memiliki kebaikan, kesopanan, kelemah-lembutan, dan kejujuran untuk nusa dan bangsa.

3. Dalam menciptakan suasana belajar yang menyenangkan diperlukan ketenangan, sukacita, dan pemberian motivasi yang kuat dan benar dalam pengajaran matematika, bukan hanya dengan kata-kata, tetapi dengan memberi rangsangan melalui kiat (strategi), trik, tehnik dan cara pengajaran yang tepat agar anak didik senang, atau tertarik terhadap matematika, sehingga dapat menghilangkan perasaan cemas terhadap pelajaran matematika.

4. Pembelajaran dengan Integrating Faith and Learning sangat memungkinkan dilaksanakan untuk materi pada bidang studi atau mata kuliah yang lain, untuk mengembangkan masingmasing kompetensi-kompetensi setiap bidang studi atau setiap mata kuliah yang sudah dituliskan dalam Kurikulum Nasional Indonesia 2013.

5. Pembelajaran dengan Integrating Faith in mathematics Teaching and Learning juga sangat memungkinkan dilaksanakan materi matematika yang lain untuk mengembangkan kompetensi matematik siswa yang lainnya, seperti kemampuan pemecahan masalah, kemampuan penalaran, kemampuan berpikir kritis dan kreatif dan kemampuan lainnya yang sudah disyaratkan pada Kurikulum Nasional Indonesia 2013. 


\section{DAFTAR PUSTAKA}

Bhudi, W. S. (2005). Langkah Awal Menuju ke Olimpiade Matematika. Jakarta. Ricardo.

Departemen Pendidikan Nasional (2002). Kamus Besar Bahasa Indonesia, Jakarta. Balai Pustaka.

Helmaheri. (2004). Mengembangkan Kemampuan Komunikasi dan Pemecahan Masalah Matematis Siswa SLTP melalui Strategi Think-Talk-Write dalam Kelompok Kecil. Bandung: Tesis UPI. Tidak Diterbitkan.

Hutagaol, K. (2007). Pembelajaran Kontektual untuk Meningkatkan Kemampuan Representasi Matematis Siswa Sekolah Menengah Pertama. Bandung. Tesis UPI. Tidak Diterbitkan. (2010). Strategi Multi Representasi untuk Meningkatkan Kemampuan Pemecahan Masalah Matematis dan Kemampuan Komunikasi Matematis Siswa Sekolah Menengah Pertama. Bandung. Desertasi UPI. Tidak Diterbitkan.

Kuntaraf, J. Dan Kathleen, K. (2007). Kearifan Allah. Jakarta. Talenta Mulia Aksara.

Kusdinar, A. dan Arifin, Z. (1992). Pendekatan dalam Proses Belajar Mengajar. Bandung. Rosdakarya.

Lembaga Alkitab Indonesia. (2006). Alkitab Suplemen. Jakarta.

Sagala, M. Berbakti, belajar setiap hari bersama Tuhan. Jakarta. Untuk kalangan sendiri.

Soedjadi, R. (1999). Kiat Pendidikan Matematika di Indonesia, Jakarta. Direktorat Pendidikan Tinggi Departemen Pendidikan nasional.

Subanji, H. (2013). Pembelajaran Matematika Kreatif dan Inovatif. Malang. Universitas Negeri Malang.

Suherman dkk. (2001). Strategi Pembelajaran Matematika Kontemporer. Bandung. Universitas Pendidikan Indonesia.

Ruseffendi, E. T. (1991). Pengantar kepada Membantu Guru Mengembangkan Kompetisinya dalam Pengajaran Matematika untuk Meningkatkan CBSA. Bandung. Tarsito.

Sihotang, P. Integritas Faith Learning, Jakarta. Untuk Kalangan sendiri.

Sitorus, J. (1990). Pengantar Sejarah Matematika dan Pembaharuan Pengajaran Matematka di Sekolah. Bandung. Tarsito.

Sobel, M. A., Maletsky, E. M., Polla, G., Suyono., Muji, D. (2002). Mengajar Matematika. Sebuah Buku Sumber Alat Peraga, Aktivitas, dan Strategi, untuk Guru Matematika SD, SMP, SMA. Jakarta. Erlangga.

Sumarmo, U. (2003). Pengembangan Model Pembelajaran Matematika untuk Meningkatkan Kemampuan Intelektual Tingkat Tinggi Siswa Sekolah Dasar. Laporan Penelitian. Bandung: Lembaga Penelitian UPI.

Supriatna, A. dkk (2012). Implementasi Lesson Study. Bandung. Rizqi Press.

Suryadi, D., Turmudi. (2008). Matematika. Bahan Ajar Pendidikan dan Latihan Profesi Guru (PLPG). Bandung. Universitas Pendidikan Indonesia.

White, E. Christian Leadership. Copyright 1996, Bandung, Indonesia Publishing House. Education. Bandung, Indonesia Publishing House.

Zain, A. dan Djamarah, B. (1995). Strategi Belajar mengajar. Banjarmasin. Rineka Cipta. 